研 究

$$
\text { ハイドロキシアパタイト/ジルコニア系混合スラリーのレオロジー }
$$

\author{
山田葉子的, 飯島 宏康的, 渡辺 龍三的 1
}

山1 東北大学大学院工学研究科材料加工プロセス学専攻, ₹ 980-8579 仙台市青葉区荒巻字青葉. 的 2 東北大学大学院工学研究科 材料加工プロセス学専攻 [(現)：西日本旅客鉄道株式会社, 金沢総合車両所, 干 924-0015 石川県松任市新田町 289].

\title{
Rheological Behavior of Hydroxyapatite and PSZ Mixed Slurries
}

\author{
Yoko Yamada ${ }^{1}$, Hiroyasu Iijima ${ }^{2}$ and Ryuzo Watanabe 1 \\ * Department of Materials Processing, Graduate School of Engineering, Tohoku University, Aramaki Aoba, Aoba-ku, Sendai $980-8579$. \\ ${ }^{2}$ Department of Materials Processing, Graduate School of Engineering, Tohoku University. \\ [Present Address: West Japan Railway Company, 289 Shinden-machi, Matto 924-0015].
}

Received December 15, 1997

\section{SYNOPSIS}

The rheological behavior of hydroxyapatite and partially stabilized zirconia mixed slurries is investigated in order to study the production of hydroxyapatite / zirconia functionally graded materials by slurry dipping method. The purpose of this material is to use as a dental implant material. The rheological behavior of hydroxyapatite and zirconia, which strongly contributes to the resultant thickness of FGM layer, is different between hydroxyapatite (Newtonian fluid) and zirconia (non-Bingham plastic fluid). The mixed slurries of hydroxyapatite and zirconia slurries show the strong contribution of zirconia when the shear rate is low, but the rheology of hydroxyapatite is dominated when the shear stress is high. On the other hand, the optimum dispersant concentration changes linearly with change in the composition of hydroxyapatite and zirconia.

KEW WORDS

rheology, slurry technology, bioceramics, hydroxyapatite, partially stabilized zirconia, implant materials

\section{1 緒言}

ハイドロキシアパタイト (以下 HAp と示す)は生体親和性に 優れた材料として注目されているが, 単独でインプラント材料 として使用するには強度が不十分である ${ }^{1,2)}$. そのため部分安定 化ジルコニア(以下PSZと示す)を始めとする生体不活性ではあ るが無害で, かつ高強度, 高鞄性な材料の複合化が試みられて いる3-10. しかし, 実際の歯や骨などに要求される性質は, 強度 だけでなく，防振性など同時多面的な特性を満たす必要がある。 このような材料を人工的に実現する方法の一つとしての材料の 傾斜機能化についてはすでに研究が進められているが(1-14)，著 者らは材料内部に強度を持たせ, 生体と接触する表面には生体 親和性を持たせたHAp/PSZ系傾斜機能材料を提案している ${ }^{15,16)}$.

このような傾斜機能材料の作製のために，従来の粉末積層法 に代わる方法として,複雑形状にも対応可能なスラリーディッ プ法を採用した。これは, 配合組成の異なるスラリー中に順次 基板を浸して引き上げることにより膜を付着させ,コーティン グ層を築いていく方法である。この成形法では, いかに粉末を 安定に分散させ, 高濃度のスラリーを調整し, 各層の膜厚を制
御するかが鍵になる。さらに適切な成形助剤を用いることによ り，従来の成形法では凝集し易い各種微細セラミックス粒子を 十分に解こうできれば微細で均一な複合組織を得ることが可能 になる、そのためスラリーの分散性を始めとするレオロジー特 性に関する研究が, HAp ${ }^{(7)}$ を始めとするセラミックス ${ }^{(8-21)} に$ 対 し，数多くなされてきている.

本研究ではこれらの研究成果を踏まえ, HAp/PSZ系傾斜機能 材料作製のための基礎的研究として，HAp およびPSZ 単独の 場合のレオロジー特性抢よびこれらを混合した HAp/PSZ系ス ラリーのレオロジー特性を調べることを目的とした。

\section{1 原料}

\section{2 試料作成および実験方法}

原料粉末は，セントラル硝子秼製の HAp 粉と東ソー(株)製の $3 \mathrm{~mol} \% \mathrm{Y}_{2} \mathrm{O}_{3}$ を含む部分安定化ジルコニア粉である. HAp 粉の $\mathrm{Ca} / \mathrm{P}$ 比は 1.67 の化学量論組成で，平均粒径は $2.0 \mu \mathrm{m}$ である. PSZ粉の一次粒子は $0.027 \mu \mathrm{m}$ であるが, 約 $100 \mu \mathrm{m}$ の球形に造粒 されている. 


\section{2 スラリーの調整方法}

HAp粉およびPSZ粉単体のスラリーを作製するには, 純水, 粉末および分散剂を同時に混合するが, HAp/PSZ 混合スラ リーの場合には，まず純水にPSZ 粉末を加えて造粒された PSZ粒子を解こうするために超音波ホモジナイザで $5 \mathrm{~min}$ 間攪 拌した後, HAp粉末と分散剤を添加した. その後, 両スラリー とも超音波ホモジナイザとスクローラで $20 \mathrm{~min}$ 覞找混合した. 2.3 レオロジー測定方法

スラリーのレオロジー測定は, 共軸二重円筒型測定型の回 転粘度計 (METTLER RM180Rheomat) を用い, 293 \pm 1 K の温度 一定下で測定した．また，スラリーのチクントロピーの影響 を防ぐために，あるせん断速度における見かけ粘度を測定す る際には，せん断力を与えてから $15 \mathrm{~min}$ 後の值を読み取るよ うにした。

過不足ない分散剂量は，分散剂の量を 10〜100 (mg/ml) に 変化させた時のスラリー粘度の変化から求めた. ここで, 分 散剂量の単位は粉末 $1 \mathrm{ml}$ に対する分散剂の固形分の重量 $(\mathrm{mg} / \mathrm{ml})$ として表示した. 一方, 結合剤には, 水溶性の結合剂 として広く用いられているポリビニルアルコール (PVA: $\left[-\mathrm{CH}_{2} \mathrm{CH}(\mathrm{OH})-\right]_{\mathrm{n}}$, 関東化学(株製, 平均重合度 500 , けん化度 $86.5 \sim 89 \mathrm{~mol} \%$, 水溶液の ph7.0) を用いた，粒子充填率は HAp 単相の場合は $45 \mathrm{vol} \%$, PSZ 単相では $30 \mathrm{vol} \%$, 混合スラリー では40vol\%とし, せん断速度 $400 \mathrm{~s}^{-1}$ における粘度をもってス ラリーの見かけ粘度とした。

3.1 分散剂および結合剂の影響

3.1.1 HAp 粉およびPSZ 粉単相スラリー

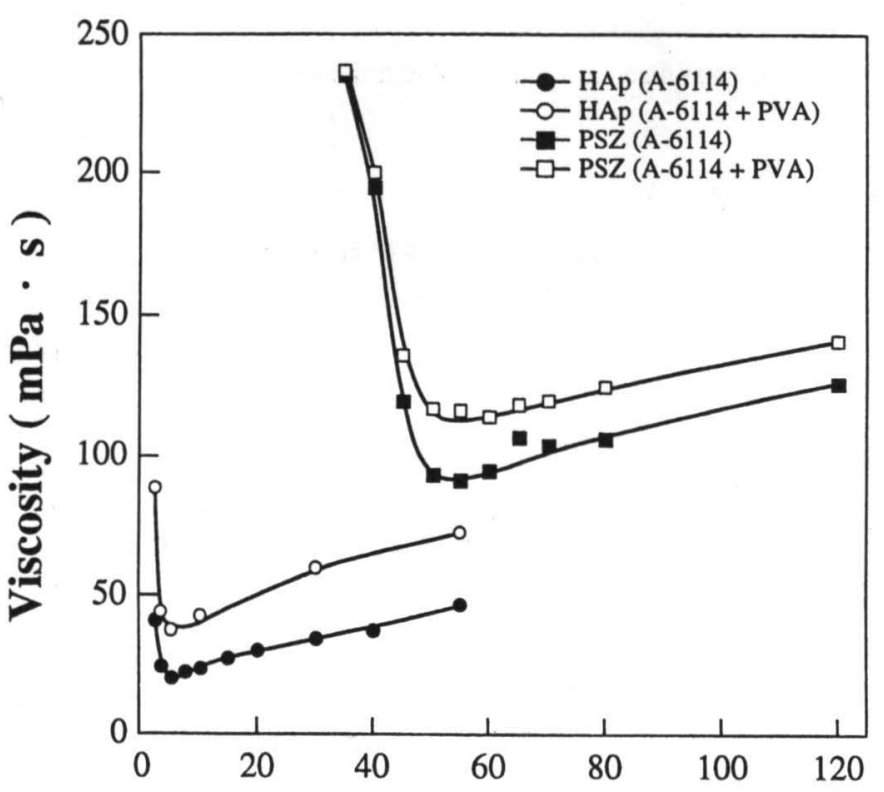

\section{Dispersant concentration $(\mathrm{mg} / \mathrm{ml})$}

Fig.1 Effect of amount of dispersant concentration on viscosity of HAp and PSZ slurries. The shear rate is $400 \mathrm{~s}^{-1}$ and the solid loading of HAp is $45 \mathrm{vol} \%$ and that of PSZ is $30 \mathrm{vol} \%$.
分散剤の種類については,これまでの研究により HApでは アニオン系1), PSZではアクリル酸オリゴマーなど2)でその有 用性が認められている。 そこで, その一種であるポリアクリ ル酸アンモニウム塩 $\left(\mathrm{PAA}-\mathrm{NH}_{4}:\left[-\mathrm{CH}_{2} \mathrm{CH}\left(\mathrm{COONH}_{4}\right)-\right]_{\mathrm{n}}\right)$ 系の A-6114(東亜合成(制製)を採用した. A-6114はアニオン系の分 散剤であり, 分子量は 10000 , 水溶液の ph は 7 9 9゙ある.

HAp粉またはPSZ粉のみの単相スラリーに分散剤および結 合剂を添加した場合の見かけ粘度の変化を Fig.1に示す.これ より, HApスラリーでは $5 \mathrm{mg} / \mathrm{ml}$, PSZスラリーでは $55 \mathrm{mg} / \mathrm{ml}$ で見かけ粘度が最小值を示し，この量でポリアクリル酸イオ ンが過不足なく粉末に吸着し, 静電立体的な反発力により粒 子が安定に分散していることがわかる。ここではこの過不足 ない分散剂量を「最適分散剂量」と呼ぶことにする。ここで, 最適分散剤量が HAp スラリーと PSZ スラリーで異なるのは, HAp 粉と PSZ粉の分散機構が同じであると仮定すると, 単位 粉末あたりの分散剤が吸着する有効表面積の違いによるもの と考えられる. HAp の粒径が $2.0 \mu \mathrm{m}$ であることから, 粒子の 有効表面積が分散剤量に比例すると考えると, 式 (1) から, PSZの有効平均粒径は $0.13 \mu \mathrm{m}$ と求まる.

$$
\begin{aligned}
& \frac{4 \pi \cdot 2.0^{2} \cdot n_{\mathrm{HAP}}}{4 \pi \cdot r_{\mathrm{PSZ}}{ }^{2} \cdot n_{\mathrm{PSZ}}}=\frac{c_{\mathrm{HAP}}}{c_{\mathrm{PSZ}}} \\
& \frac{3 \pi / 4 \cdot 2.0^{3} \cdot n_{\mathrm{HAP}}}{3 \pi / 4 \cdot r_{\mathrm{PSZ}}{ }^{3} \cdot n_{\mathrm{PSZ}}}=\frac{V_{\mathrm{HAP}}}{V_{\mathrm{PSZ}}}
\end{aligned}
$$

ここで, $n_{\mathrm{HAp}}, n_{\mathrm{PSZ}}$ はそれぞれ HAp, PSZの粒子数, $c_{\mathrm{HAp}}, c_{\mathrm{PSZ}}$ は 最適分散剂量, $V_{\mathrm{HAp}}, V_{\mathrm{PSZ}}$ は粒子充填率, $r_{\mathrm{PSZ}}$ は $\mathrm{PSZ}$ 粒子の直 径である. 実際の PSZ 粉の一次粒子が $0.027 \mu \mathrm{m}$, 凝集した二 次粒子が $100 \mu \mathrm{m}$ であることを考慮すると, PSZをスラリー化 することにより二次粒子の解こうが進行し, 材料組織が微細 化していることが予測される．Fig.2にPSZを 20vol\% 含む組 成について，スラリー法により HAp と PSZを混合した後， $1573 \mathrm{~K}, 200 \mathrm{MPa}, 60 \mathrm{~min}$ の条件下で熱間等方圧成形(HIP)によ り焼結した試料を示す.X線回折から, HApの分解が起きて

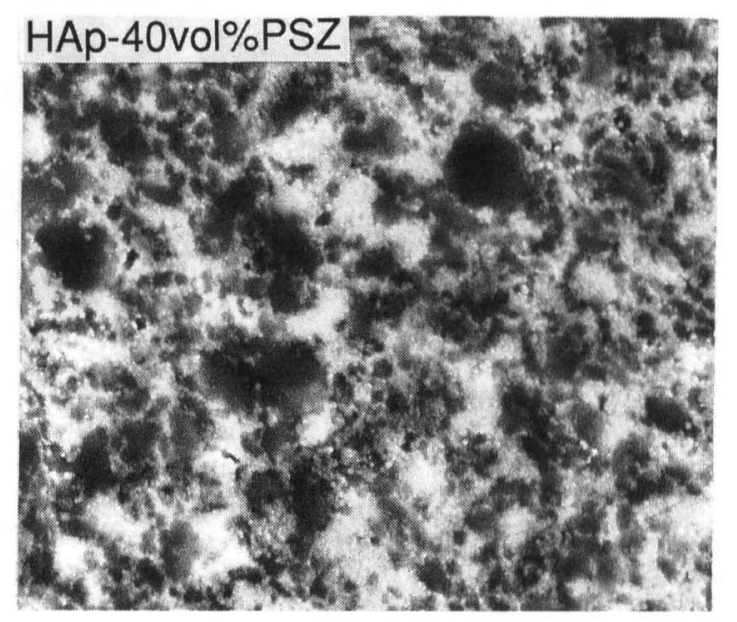

Fig.2 SEM micrograph of HAp-20vol\%PSZ composite produced by slurry technology. The sintering condition of HIP is at $1573 \mathrm{~K}$ for $60 \mathrm{~min}$ in $200 \mathrm{MPa}$. 
いないことが確認されている ${ }^{15}$. 写真より，PSZ(白色部分)は $0.1 \mu \mathrm{m}$ 以下から最大でも $1 \mu \mathrm{m}$ 以下に解こうされていることか ら,式(1)から求めた粘度測定による粒径の予測值とほぼ一致 することがわかった。このことから，従来行われてきた粉末 混合法に比べ 22)，スラリー化による混合によって組織を微細 化できることが確認された。

結合剤の影響を調べるために, 30 $\mathrm{mg} / \mathrm{ml}$ のPVAを添加した 場合の粘度変化を Fig.1 伯抜きで示してある。これを見る と, 結合郕の添加により全体的に粘度は上昇したが，最適分 散剤量には変化は見られない，また，曲線の傾きも分散剂の みを添加したときのものと一致している。このことから，分

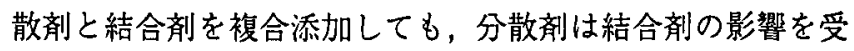
けずに粒子表面に吸着し分散哓としての機能を果たし，一方 結合片は，粒子表面に吸着している分散凨を脱離させること なくスラリーの粘度上昇のみに寄与することがわかった。 よって，本系スラリーに拉いては，PVA量を変化させること によりスラリーの粘度を自由に制御できることがわかった。

3.1.2 HAp 粉および PSZ 粉の混合スラリー

Fig.3にPSZの組成を 20,40,60,80vol\%に変化させた各混合 スラリーの, 分散片量と粘度の関係を示す.スラリー中のPSZ 体積分率の增加に伴い最適分散材料と粘度は增大した，最適 分散剂量が分散剂の吸着する有効表面積のみで決まるならば， 各組成のスラリーの最適分散剂量は組成と線形になるはずで ある。そこで, PSZの体積分率と最適分散剤量の関保をプロッ トしてみると,Fig.4に示すように破線で示した線形則による 予測值と実験值はほほ一致し，前節の結果からも各組成の最 適分散片量は分散凨の吸着する有効表面積のみで決まると結

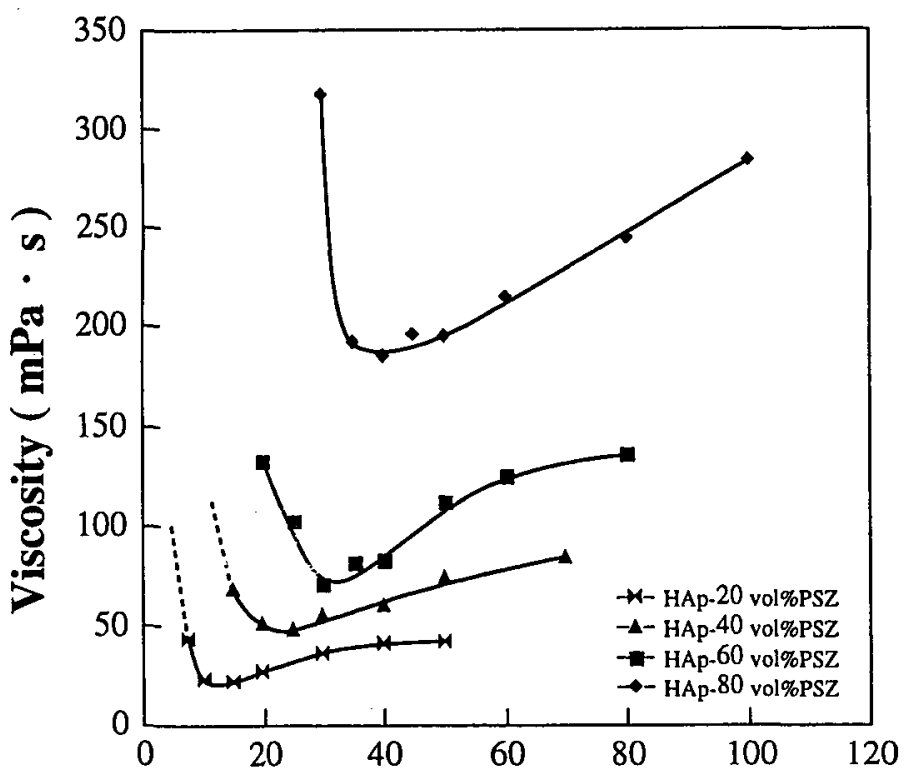

Dispersant concentration ( $\mathrm{mg} / \mathrm{ml}$ )

Fig.3 Effect of the amount of dispersant concentration on viscosity of HAp and PSZ mixed slurries. The shear rate is $400 \mathrm{~s}^{-1}$ and the solid loading is $40 \mathrm{vol} \%$.
論づけられる，よって，他の組成のスラリーを調製する場合 でも，これらの結果を用いてその最適分散剂量を決定するこ とができる。

\section{2 流動曲線}

Fig.5(a) および(b)に，分散剤量を变化させた時のHApおよ びPSZの流動曲線をそれぞれ示す，分散扸量は不足量, 最適 量, 過㮃量とした. HAp スラリーでは, 分散剤量が不足して いると弱いチクソトロピーを示すことが，過剩量では，全体 に曲線は高せん断応力側に上昇するもののチクントロピーを 示さないことがわかったこれは分散剤量が不足していると， 解こうされずに凝集したHAp粒子がスラリー中に存在するた め，構造破壊に起因するチクソトロピーを示したものと考え られる。また分散剂を過㮃に添加した場合には，粒子はすで に解こうされて扔り分散剂による粘度上昇だけが起こるため, チクソトロピーを示さなかったと考えられる．同様な挙動が PSZスラリーでもみられ，分散剤が不足するとそのチクソト ロピー性が増大するものの，過㮃の時には曲線の形態はそれ ほど変化しない。

Fig.6に各混合スラリーにそれぞれ最適分散剤量を添加した ときの流動曲線を示す。なおせん断速度は，単相スラリーの 場合と同様の $50 \sim 1100 \mathrm{~s}^{-1}$ の範囲で変化させた．全体的には PSZの体積分率が大きくなるにつれ，擬塑性流体から降伏值 をもつ非ビンガム塑性流体へと変化し，そのチクソトロピー の度合も次第に強くなることがわかった。しかし，例えばPSZ を20vol\%含んだスラリーに注目すると，高せん断速度領域で はHApによるダイラタンシーがみられ，PSZとHApのレオロ ジー特性が同時に現われている。

3.3 粘度

最適分散剤量を添加したときの，せん断速度と粘度の関係

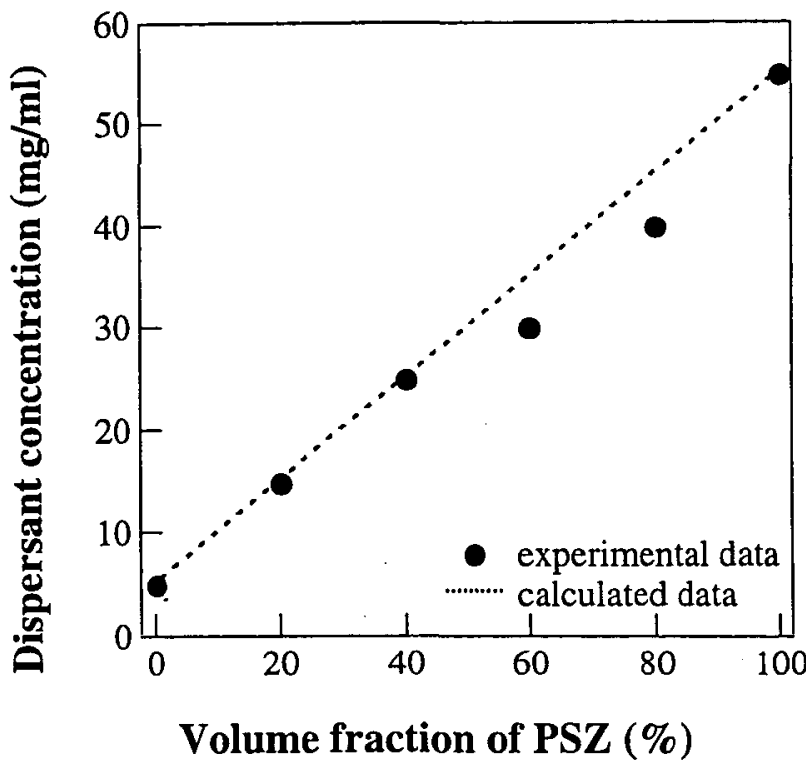

Fig.4 Optimum dispersant concentration corresponding to the different volume fraction of PSZ. The shear rate is $400 \mathrm{~s}^{-1}$ and the dispersant is A-6114. 

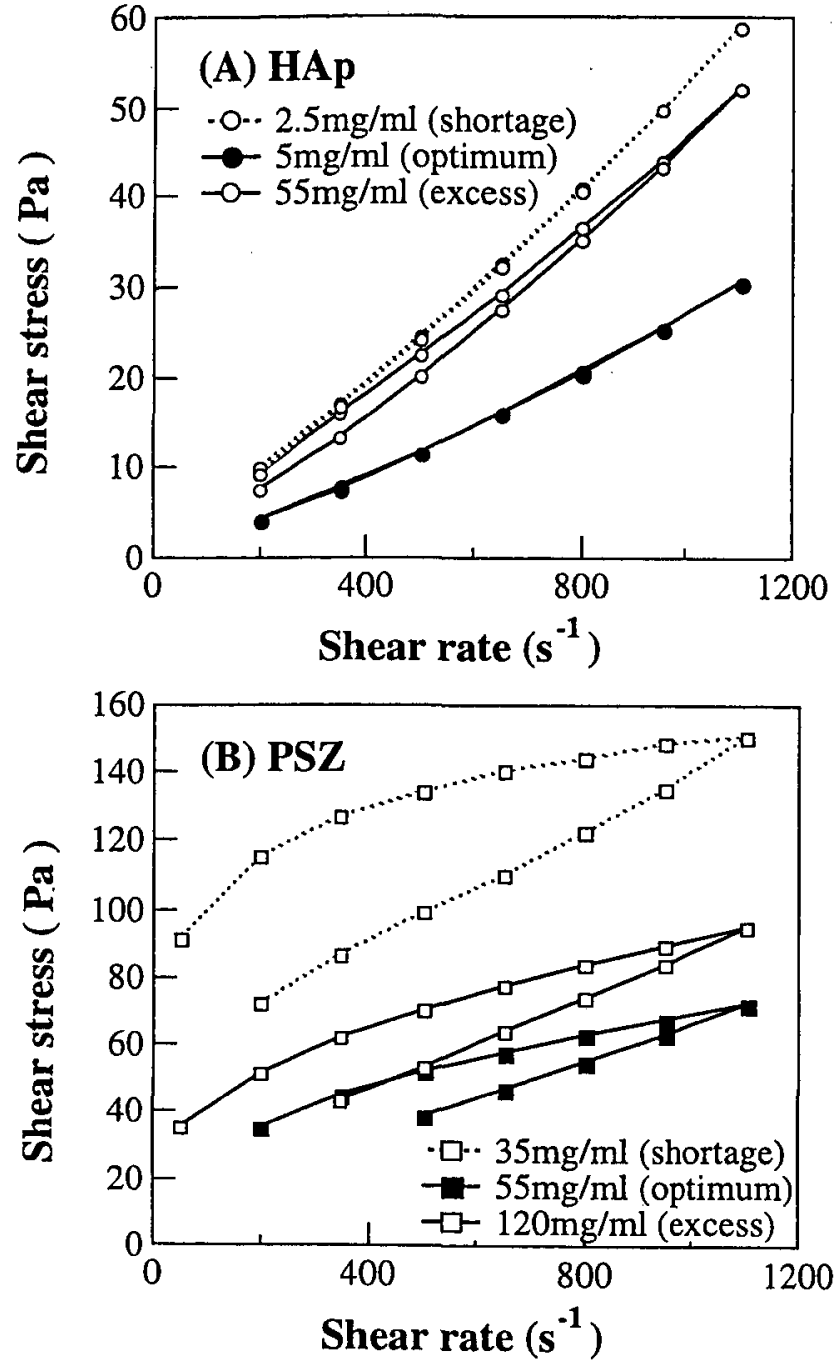

Fig.5 Rheogram for (A) HAp and (B) PSZ when the dispersant concentrations are in three different conditions; excess, optimum and shortage. The solid loading of the HAp slurry is $45 \mathrm{vol} \%$ and the PSZ slurry is $30 \mathrm{vol} \%$.

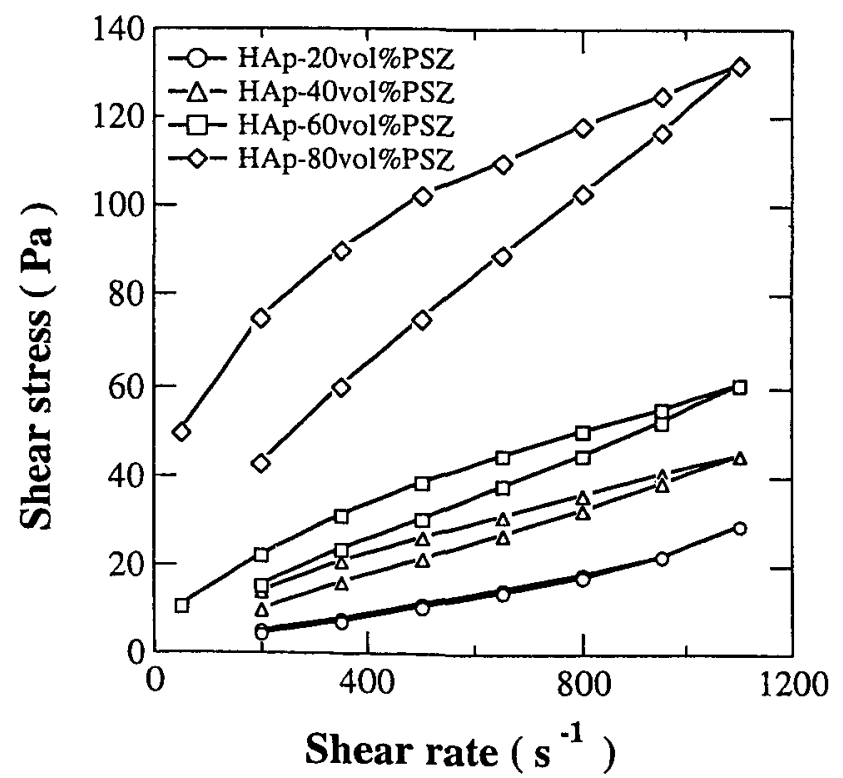

Fig.6 Rheogram for 20, 40,60 and 80vol\%PSZ included mixed slurries. The solid loading is $40 \mathrm{vol} \%$.
をFig.7に示す。HApスラリーおよびPSZ スラリーの結果を (A)に, PSZ粉を 20vol\%含むスラリーの結果を(B)に示してい る。これより，粒子凝集体の構造破壊が起こるPSZスラリー では，せん断速度つまりせん断力が増大するにつれ粘度は減 少することがわかる，また，ダイラタント流体の HAp スラ リーでは，逆にせん断速度の増大とともに粘度は上年してい るが，その変化はPSZスラリーに比べればかなり小さい，一 方，PSZ粉を 20vol\%含むスラリーの場合には，せん断速度の 低速度領域では粘度は減少しており，PSZ粒の凝集破壊が起 こっていると考えられる，中速領域では粘度は一定となり， あたかもニュートン流体のような挙動を示している。これは PSZスラリーに扔ける凝集粒の破壊と, HAp スラリーのダイ ラタンシーが平衡状態になっているためと考えられる，高速 領域ではPSZの凝集破壊はほほ完了し，HApのダイラタン
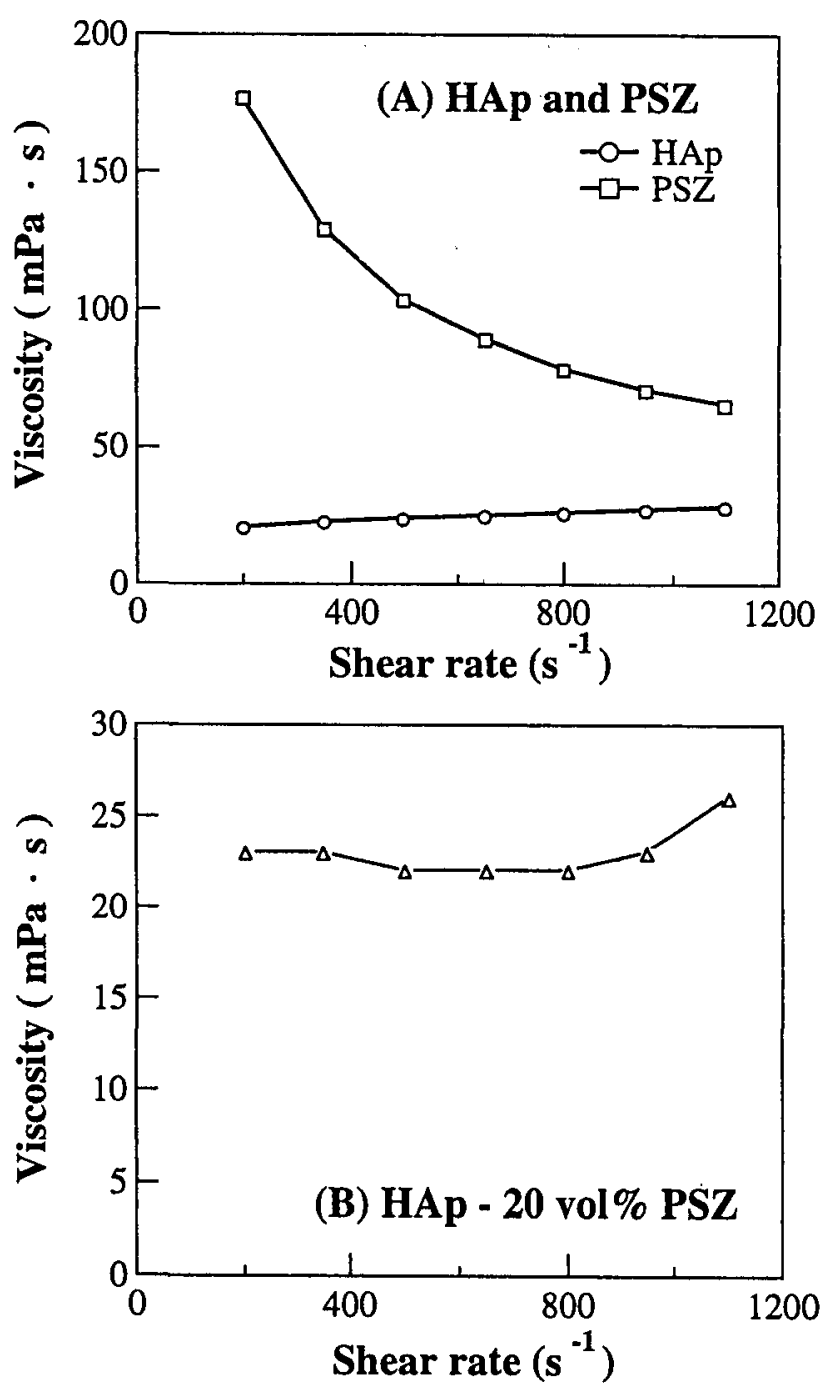

Fig.7 Viscosity of (A) HAp and PSZ, and (B) HA $\pi$-20vol\%PSZ with different shear rate. The solid loading of HAp is $45 \mathrm{vol} \%$ and PSZ is $30 \mathrm{vol} \%$ and the optimum amount of dispersant concentration is added. The solid loading for HAp$20 \mathrm{vol} \% \mathrm{PSZ}$ is $40 \mathrm{vol} \%$ and the dispersant concentration is $15 \mathrm{mg} / \mathrm{ml}$. 
シーが現われたものと考えられる。他の組成の混合スラリー においてもHApとPSZのレオロジーが複雑に絡み合った挙動 を示していると推察されるが, PSZのレオロジーが優勢であ るためか，そのような挙動は現われなかった。

そこで，せん断速度を $400 \mathrm{~s}^{-1}$ 一定にした場合の PSZの組成 と粘度との関係(Fig.8)をみてみると, 粘度の対数と PSZの体 積分率がほぼ線形になっており，粘度に対するPSZの奇与の 大きさがうかがえる、これは，HApがニュートン流体である のに対し PSZが非ビンガム塑性流体であり，このせん断速度 ではPSZ粒の構造破壊が終了していないため, 混合スラリー 全体としての粘度に対しては構造破壊が進行するPSZ粒の寄 与が大きくなったことに起因するものと考えられる，

\section{4 ま と}

(1) HAp, PSZスラリーともにそれぞれ異なる最適分散鼡量 を持ち，この值は結合剤の影響を受けない. HAp/PSZ混 合スラリーについては，その分散性は成分間の相互作用 を持つことはなく独立に作用しており，その值は粉末粒 子の有効表面積に依存している。そのため，混合スラ リーの最適分散剤量はPSZの体積分率に対して線形に変 化する。

(2) HAp/PSZ 混合スラリーの流動曲線は, PSZの体積分率が 大きくなるにつれ，擬塑性流体から降伏值をもつ非ビン ガム塑性流体へと変化し，そのチクソトロピーの度合も 次第に強くなる。

（3）HApスラリーは単独ではニュートン流体に近い性質を示 し，PSZスラリーはせん断速度の増加に伴い凝集構造が 破壊されるために粘度は減少する。しかしHAp/PSZ混合 スラリーでは, 低せん断速度域ではPSZの凝集破壊が進

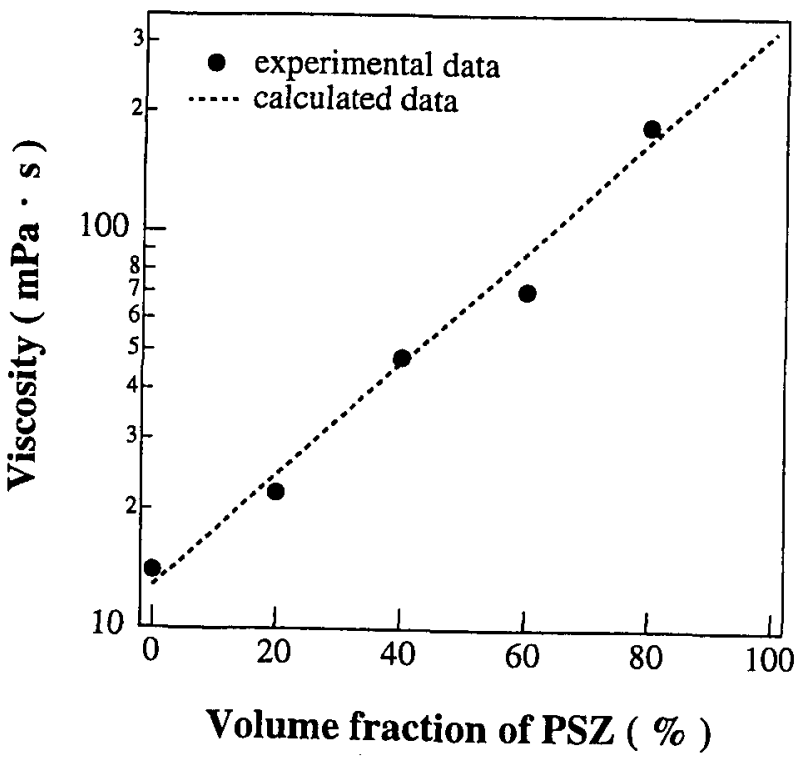

Fig.8 The relationship between viscosity and the volume fraction of PSZ when the dispersant concentration is optimum. The shear rate is $400 \mathrm{~s}^{-1}$ and the solid loading is $40 \mathrm{vol} \%$.
行するためPSZの性質が強く現れるが，凝集破壞が終了 する高せん断速度域ではHApの性質が強く流動曲線に現 れる。

\section{文献}

1）亀山哲也："自然に学ぶバイオセラミックス",まてりあ, 33(1994)552-558.

2) R.Z.LeGeros and J.P.LeGeros: "An Introduction to Bioceramics", Advanced Series in Ceramics-Vol.1, ed. L.L. Hench and J.Wilson, (1993)181.

3) E.Chang, W.J.Chang, B.C.Wang and C.Y.Yang: "Plasma Spraying of Zirconia-Reinforced Hydroxyapatite Composite Coatings on Titanium", J. Mater. Sci.: Materials in Medicine, 8(1997)193-200.

4）松野昂士,渡辺健一,小野畫次, 小石県純: "ジルコニア被 覆水酸アパタイト微粒子の焼結 ", J. Ceram. Soc. Japan, 104(1996)945-948.

5) J.Li, L.Hermansson and R.Sooremark: "High-strength Biofunctional Zirconia: Mechanical Properties and Static Fatigue Behaviour of Zirconia-apatite Composites", J. Mater. Sci.: Materials in Medicine, 4(1993)50-54.

6) M.Takagi, M.Mochida, N.Uchida, K.Saito and K.Uematsu: "Filter Cake Forming and Hot Isostatic Pressing for TZPdispersed Hydroxyapatite Composite", J. Mater. Sci.: Materials in Medicine, 3(1992)199-203.

7) 井奥洪二, 宗宮重行, 吉村昌弘："ポストシンタリングに よる準安定正方晶ジルコニア粒子分散アパタイトセラ ミックス ", 日本セラミックス協会学術論文誌, 99(1991) 196-203.

8) J.C.Lee, K.N.Subramanian and Y.Kim: "The Influence in $\mathrm{Al}_{2} \mathrm{O}_{3}$ Particulate-Reinforced Aluminum Alloy Composite and its Role on the Tensile Properties", J. Mater. Sci., 29(1994)1983-1990.

9) P.Ducheyne, M.Marcolongo and E.Schepers: "An Introduction to Bioceramics", Advanced Series in Ceramics-Vol.1, ed L.L.Hench and J.Wilson, (1993)281.

10) E.Champion, S.Gautier and D.Bernache-Assollant: "Characterization of Hot Pressed $\mathrm{Al}_{2} \mathrm{O}_{3}$-platelet Reinforced Hydroxyapatite Composites", J. Mater. Sci.; Materials in Medicine, 7(1996)125-130.

11) F.Watari, A.Yokohama, F.Saso, M.Uo and T.Kawasaki, "Functionally Gradient Dental Implant Composed of Titanium and Hydroxyapatite", Proc. $3^{\text {rd }}$ Int. Symp. On Structural and Functional Gradient Materials, (Lausanne), (1995)1-6.

12) 亘理文夫: "傾斜機能人工歯根", 七ラミックス, 29(1994) 191-193.

13) 高橋秀直: "歯科用傾斜機能材料の研究", 歯科材料. 器械, 12(1993)595-612.

14）荒田顕司, 武内信貴, 芳仲捷, 廣田健, 山口修: “湿式加圧 成形法を用いた $\mathrm{MoSi}_{2} / \mathrm{ZrO}_{2}\left(2\right.$ モル\% $\left.\mathrm{Y}_{2} \mathrm{O}_{3}\right)$ 系傾斜機能材料 
の作製 ", 粉体および粉末治金, 44(1997)565-569.

15) 飯島宏康: 東北大学修士学位論文, (1997).

16）飯島宏康, 山田葉子, 渡辺龍三: "ハイドロキシアパタイ トジルコニア系スラリーのレオロジー", 粉体粉末治金協 会平成 8 年秋季大会講演概要集, (1996)75.

17) F.Lelievre, D.Bernache-Assollant and T.Chartier: "Influence of Powder Characteristics on the Rheological Behaviour of Hydroxyapatite Slurries", J. Mater. Sci.: Materials in Medicine, 7(1996)489-494.

18）佐野三郎ら："Y-PSZの泥しょう鋳込成形と焼結（第 1 報) 一泥しょう調整条件の検討一", 粉体および粉末治金，
44 (1997)876-880.

19）奥本良博, 安宅健, 近藤祥人, 石崎幸三: “アルミナ・スラ リーの分散特性が顆粒とプレス成形体の組織に及ぼす影 響 ", J. Ceram. Soc. Japan, 105(1997)771-774.

20) R.S.Premachandran and S.G.Malghan: "Dispersion Characteristics of Ceramic Powders in the Application of Cationic and Anionic Polyelectrolytes", Powder Technology, 79(1994)53-60.

21) 斎藤勝義：ファインセラミックスの成形と有機材料，(侏) シーエムシー , (1985)203.

22) 山田葉子: 東北大学博士学位論文, (1995). 